\title{
Stewardship: Tradition preservation, resilience based on faith
}

\section{Mayordomía: Conservación de una tradición, resiliencia basada en la fe}

\author{
MORALES-PAREDES, Yesbek Rocío $\dagger^{*}$, CERÓN-CARRILLO, Teresa Gladys, SANTIESTEBAN- \\ LÓPEZ, Norma Angélica and MALDONADO-RESÉNDIZ, Jorge Ángel
}

Benemérita Universidad Autónoma de Puebla, Faculty of Administration

ID $1^{\text {st }}$ Author: Yesbek Rocío, Morales-Paredes / ORC ID: 0000-0003-1740-2682, Researcher ID Thomson: W-3233-2019, CVU CONACYT ID: 296456

ID $1^{\text {st }}$ Coauthor: Teresa Gladys, Cerón-Carrillo / ORC ID: 0000-0002-3492-379X, CVU CONACYT ID: 211348

ID $2^{\text {nd }}$ Coauthor: Norma Angélica, Santiesteban-López / ORC ID: 0000-0001-7700-4139, Researcher ID Thomson: X-70692018, CVU CONACYT ID: 249825

ID $3^{\text {rd }}$ Coauthor: Jorge Ángel, Maldonado-Reséndiz /ORC ID: 0000-0003-1787-3660, CVU CONACYT ID: 1087863

DOI: $10.35429 /$ EJC.2020.6.10.20.30

Received April 18, 2020; Accepted June 30, 2020

\begin{abstract}
Considered as a religious tradition ingrained in many Mexican communities, the stewardship continues present, facing social and cultural changes that have made it disappear in capital cities. The objective of the present study is to highlights the stewardship importance in San Rafael Comac and Santo Domingo Tonahuixtla communities in, Puebla, Mexico, where the tradition persists, preserves and is spread, considering it as a resilience method for people, based on hope, faith and trust in their social and cultural environment. The qualitative research methodology used was Oral History, approached through interviews with the main actors of this study: the mayordomos, who share their experience on the religious position with respect, honor and privilege, with the firm conviction of preserving the tradition.
\end{abstract}

Stewardship, Resilience, Faith

\begin{abstract}
Resumen
La mayordomía, considerada como una tradición religiosa arraigada en diversas poblaciones de la República Mexicana, continúa vigente en algunas comunidades, enfrentando cambios sociales y culturales que la han hecho desaparecer en las urbes capitalinas. El objetivo de este proyecto es describir la importancia de la mayordomía en las poblaciones de San Rafael Comac y Santo Domingo Tonahuixtla, Puebla, México; en donde dicha tradición aún persiste, se conserva y se difunde, como un método de resiliencia para los pobladores, basada en la superación de circunstancias adversas por medio de la esperanza, la fe y la confianza en su entorno social y cultural. La metodología de investigación cualitativa utilizada fue la Historia Oral, abordada por medio de entrevistas a los actores principales de este estudio: los mayordomos, quienes comparten con respeto, honor y privilegio su experiencia en el cargo religioso, con la firme convicción de dar a conocer y preservar la tradición.
\end{abstract}

Mayordomía, Resiliencia, Fe

Citation: MORALES-PAREDES, Yesbek Rocío, CERÓN-CARRILLO, Teresa Gladys, SANTIESTEBAN-LÓPEZ, Norma Angélica and MALDONADO-RESÉNDIZ, Jorge Ángel. Stewardship: Tradition preservation, resilience based on faith. ECORFAN Journal-Republic of Colombia. 2020. 6-10: 20-30

\footnotetext{
* Correspondence to Author (email: yesbek.morales@ correo.buap.mx)

$\dagger$ Researcher contributing as first author.
} 


\section{Introduction}

Description, religious basis, activities and selection processes of stewardship as a resilience method in San Rafael Comac and Santo Domingo Tonahuixtla communities are the main focus of this article.

Geographical and populational context of the municipalities of San Andrés Cholula and San Jerónimo Xayacatlán belonging respectively to San Rafael Comac and Santo Domingo Tonahuixtla are mentioned in the first part. Then description of the populations according to the moment in which the interviewed persons held the position. Finalizing with some important data of the butler and their management.

A brief historical stewardship's review, its activity and communities' selection process was stablished. According to Montes and Montes (2014) stewardship is the result of a political and religious organizational system that is still active. So, during its management, the butlers, are gambling to improve their prestige, since stewardships are ranked as a high hierarchy leadership that needs to be maintained for the community to keep alive (Ochoa, 2007: 4).

Immediately, stewardship is proposed as a resilience method among populations, addressing this activity as an act of faith and devotion. This, emphasized that their motivations and religious basis are grounded in their "service to God" or in the fulfillment of a citizen obligation. Resilience at this point, is understood as a dynamic process that implies both adversity's exposition (as the overcoming of these adversities) and the successful adaptation of the person (Ospina, 2007: 58).

Finally, the methodology used for the study, the oral history, results and conclusions with regard to the management and the preservation of stewardship as a method of resilience in the studied places are presented.

So, the objective of this studied was to define the reason why stewardship is consider as a faith based method of resilience for those who had, have and will exercise this function in a community.

\subsection{San Andrés Cholula: San Rafael Comac}

According to the National Institute for the Federalism and Municipal Development, San Andrés Cholula municipality is located in the center west zone of Puebla state. It was constituted as a municipality September $14^{\text {th }}$ 1861. It has an approximate population of 100,439 inhabitants (Instituto Nacional de Estadística y Geografía INEGI, 2005).

Commerce and agriculture are its main economic activities. In 1897 this municipality was divided in a head municipality (Sn Andrés Cholula) and six towns: (Municipal Government. of San Andrés Cholula, 2015)

\section{- San Francisco Acatepec \\ - San Antonio Cacalotepec \\ - San Luis Tehuiloyocan \\ - Santa María Tonanzintla \\ - San Bernardino Tlaxcalcingo \\ - San Rafael Comac: research object. Corn and bean agriculture is its main activity along with poultry breading. Is located next to the head municipality (nowadays, only separated by a few streets). It has 2,300 inhabitants.}

San Rafael Comac is a little town that in mid-November, displays multiple color flower arches, saints' images, the Virgen de Guadalupe and the Santísima Virgen de los Remedios in its gate. It also has one XVII century church and it is currently the reunion center of the location.

Church bells ring every morning exactly at 11:45 am to announce that the mass is about to begin. People begin to arrive until the $t$ precinct is full. Prosecurtor, people responsible of the "varitas" (sticks) of community's religious images and Mr. Rafael Ocoxtle Jiménez, 20152016 "varita" of the "Preciosa Sangre" butler of San Rafael Comac. According to Mr. Ocoxtle, every religious image has its own "varita" (long, thin stick with multiple colors and decorations) and a commission, each one with its own activities (floral ornaments, church's cleaning, gates ornaments with floral arches) and celebration according to the date of the image's commemoration. The stewardship's "varita" in San Rafael Comac has the image of the "Preciosa Sangre". 
Twenty-eight years old, Mr. Rafael Ocoxtle Jiménez, driver for 14 years, lives in a concrete house just a few blocks away from the church. It has a large yard/parking, where some dogs guard three water pipes, being this the family's support. Mr. Ocoxtle's family is formed by his wife (housewife) and a child.

Living room, in which the interview was held, is the first room in a long, full of doors, hall. It was filled with Christmas ornaments and huge Christmas nativity, figures wrapped with newspaper, which will be place in church in December $18^{\text {th }}$ as one of the multiple stewardship's activities.

\subsection{San Jerónimo Xayacatlán: Santo Domingo Tonahuixtla}

This municipality (which head municipality carry the same name), is located in the southcenter of Puebla state. Was constituted as a free municipality in 1895. It was independent from ancient Acatlán district, maintaining corn and beans sowing as the main economic activity (Fernández, Hernández, Enríquez, et al. 2010). According to data obtained form INEGI (2005), municipality have 3,777 inhabitants, being 1757 men. San Jeronimo have fourteen localities, being the main ones: the head municipality, Galindo Barreda and Santo Domingo Tonahuixtla.

Santo Domingo Tonahuixtla: is a small town located just 8 kilometers from head municipality, its population is approximately of 764. Its main economic activity is corn sowing (Fernández, Hernández, Enriquez, et al., 2010)

Sixty-eight years old Mr. Delfino Martínez (interviewed November $20^{\text {th }}$ 2018), butler of Santo Domingo Tonahuixtla between 1976-1978, said that back then size population were smaller than now and because of its closeness to some Oaxaca's municipalities, it still preserve some indigenous tongues of the state.

The now retired ex butler, indicates that his work in the fields (as a peasant) those years, paid him from six to eight pesos a day with working periods from four in the morning until late hours in the afternoon.
Mr. Martínez also said that after his stewardship, back in 1979, he moves to México City where he lives for 34 years. His early work in the city was as a nightwatchman of a building for 10 years. Afterwards, he worked as a builder and finally as a driver from 1990 to 2013.

Today, Mr. Delfino Martínez lives in Santo Domingo Toahuixtla.

\subsection{Traditional Position System: stewardship}

"Traditional Position System (Stewardship) was one of the Spanish installed institutions as a form or evangelization and autochthonous control" (Bonfil, 1988; 165, cited in Ochoa: 2007:2). Stewardship origins are forwarder to the colonial time, when a population was organized around a place, as a town or a neighborhood can be, or also around an activity: such as bakers and weavers. A brotherhood was constituted by a community or craftsman group, and each brotherhood organized and finance the festivities of its patron saint. A butler is chosen to lead the brotherhood, who looked after the appropriate use of the resources besides the festival organization.

Over time, and because of the changes, the butler has formed part of the position system ( a form of social and political organization in Mexican indigenous communities where citizens need to render community services, it starts from simpler to more important positions being one of them the butler) and acquired the responsibility of finance the saint patron festivities (Montes and Montes, 2014:9).

Montes, O and Montes, O. (2014) mentioned (...) "position system is defined as the political religious organization found in indigenous communities in México. Through this, power has been executed and religious festivities (stewardship) has been organized". This system is preserved as a volunteer tradition that "born from the heart" according to the actual butler of San Rafael Comac, and also, in the words of the ex-butler of Santo Domingo Tonahuixtla, is an activity that must be fulfilled as a helpful and believer citizen.

Ochoa (2007: 4) mentioned that: the butler is specially a well-known and recognized habitant by their born community and in most cases their residence community. 
In the time in which the position is executed, the butler is looking for improve his prestige since stewardships are value as a high hierarchy position that need to be done for the community to keep alive.

However, Mr. and Ms. Ocoxtle (in an interview done in November $\left.16^{\text {th }}, 2018\right)$, the position was looked not for prestige but for "pleasure, tradition preservation, faith and devotion to the Lord", since they don't wait for any kind of benefit, only to "serve the Lord since He will look out for them"

\subsection{Stewardship activities in San Rafael Comac}

According to Ochoa (2007: 8):

Butler's obligations are: to give maintenance, clean and decorate the church with flowers, watch over alms, organize all year religious parties including collecting participation fee from all community families. The fee is used to pay expenses as church flower decoration, mariachis, music band and singer payment, candle sticks fireworks and firecrackers. Another important butler's obligation is to serve breakfast, meal and dinner to the music band and the people that come into his house to eat.

Mr. Ocoxtle (2018) stated in an interview that every $1^{\text {st }}$ of July, varita of the "Preciosa Sangre" stewardship in San Rafael Comac position is received with a one-year designation. Stewardship is given to a couple (woman and men) being the following the activities that they need to attend:

- Conforming a 35-person commission who should contribute with time (companion) and money for every church celebration and activities throughout the stewardship's management year, including "fiestas patronales" and "posadas" as shown in Table 1.

- Assign a godmother that willingly take over all celebration masses during the stewardship.

- $\quad$ Assist to the Sunday masses

- $\quad$ Assist to the festivities and anniversary celebrations of every "varita" image as well as the saint patron of the town: San Rafael (October $24^{\text {th }}$ ).
- Deliver the "correspondencia" (bread and fruit) to the godmother in each mass or celebration that she supports in.

- $\quad$ Hire the music bands and music groups for February $2^{\text {nd }}$ and Holy Week.

- Collect money for the commission to pay celebration expenses (in case of the money wouldn't be enough, the butler's couple should cover all the expenses)

- Food preparation, normally mole and drink for the whole town assisting to the celebrations.

- $\quad$ Define successor butler for the next year management.

\begin{tabular}{|c|c|}
\hline Date & Activity \\
\hline July 1st & Stewardship reception \\
\hline August 15th & $\begin{array}{l}\text { "Acostadita de la Santísima Virgen" (Holy } \\
\text { virgin Lay down) and mass of the crowning } \\
\text { of the Virgin. Placement of the flowers, } \\
\text { fruits and carpet. Godmother gives some } \\
\text { "chicharrín"1 or ice cream and then, she offer } \\
\text { a "taquito" in her place. }\end{array}$ \\
\hline $\begin{array}{l}\text { November } \\
\text { 2nd }\end{array}$ & Deceased mass \\
\hline $\begin{array}{l}\text { December } \\
12 \text { th }\end{array}$ & $\begin{array}{l}\text { God child dropped with the godmother and } \\
\text { "correspondencia" deliver. Godmother gives } \\
\text { "taquito or frijolitos" to the comission. }\end{array}$ \\
\hline $\begin{array}{l}\text { December } \\
\text { 12th to 23th }\end{array}$ & Twelve "posaditas" \\
\hline $\begin{array}{l}\text { December } \\
18 \text { th }\end{array}$ & $\begin{array}{l}\text { Nativity placement (new pieces every year) } \\
\text { inside church }\end{array}$ \\
\hline $\begin{array}{l}\text { December } \\
24 \text { th }\end{array}$ & $\begin{array}{l}\text { "Acostadita" and mass of the God Child. } \\
\text { Godmother gives food }\end{array}$ \\
\hline $\begin{array}{l}\text { December } \\
\text { 25th }\end{array}$ & Nativity mass \\
\hline January 6 th & $\begin{array}{l}\text { Mass and "correspondencia" deliver to the } \\
\text { Godmother plus a "Rosca de Reyes" for the } \\
\text { whole town. Godmother gives a "taquito" or } \\
\text { "wathever God's will" }\end{array}$ \\
\hline $\begin{array}{l}\text { February } \\
\text { 2nd }\end{array}$ & $\begin{array}{l}\text { Mass and celebration of the "Santa } \\
\text { Candelaria". A group is taken to the } \\
\text { Godmother since she is incharge of offer } \\
\text { food and drink. }\end{array}$ \\
\hline \multirow{3}{*}{$\begin{array}{l}\text { Holy Week } \\
\text { activities }\end{array}$} & Ash Wednesday \\
\hline & $\begin{array}{l}\text { Every Friday, until holy Friday a procession } \\
\text { is organizaed (season placement). A band is } \\
\text { hired for every one of the seven Fridays. } \\
\text { Holy thusday and Friday, breakfast, meal } \\
\text { and dinner is offered (Holy Friday meal is } \\
\text { provided by the butler consisting of } 4 \text { to } 6 \\
\text { fish and shellfish-based dishes, other food } \\
\text { are provided by another member of the } \\
\text { commission). }\end{array}$ \\
\hline & $\begin{array}{l}\text { "Viacrucis" (Way of the cross). } \\
\text { "Correspondencia" is deliver to the Jesus to } \\
\text { be. }\end{array}$ \\
\hline
\end{tabular}

Table 1 "Preciosa Sangre" Stewardship's dates and activities in San Rafael Comac

Source: Compilation based on information obtained from Mr. Rafael Ocoxtle Jiménez interview (November, 2018) 


\subsection{Santo Domingo Tonahuixtla Stewardship activities Actividades de la mayordomía en Santo Domingo Tonahuixtla}

A well-detailed description of the Butler's activities from 1976 to 1978 was given by Mr. Martínez. He mentioned that Santo Domingo Tonahuixtla designation has a three yearduration. Through these years the butler is in charge of organize the festivities every three easter Friday in honor of the "Lord de Tepalcingo" with the following activities:

- Organized a 25 people-commission who collaborate in the stewardship (in the selection process section it is described the composition of the commission).

Visit the 27 believers of the "Lord de Tepalcingo", brotherhoods with threemonth anticipation (each one composed by 15 to 25 persons). This activity, back then, was realized using dirt roads or by horse. For this reason, working days started since three in the morning y ended until nine or ten in the evening. Nowadays, there are 40 brotherhoods including San Gabriel Chilac (towards Tehuacán city), Santo Tomás, Santiago Chazumba and Santo Domingo Tianguistengo in Oaxaca State, among others are invited to participate for them to donate (as a religious promise) in kind. As an example, San Gabriel Chilac brotherhood's donation was their famous "torito" (a hollow bull of approximate one and a half long and as wide as a human to fit in, it is elaborated from paperboard and coated with firecrackers and pyrotechnics using an entertainment for people).

- Visit town houses to collect money and stuff for the celebration

Designate to each one of the members of the stewardship commission, the responsibility of a brotherhood for the festivities: flower coating, looking for lodging (some people of the town offer their houses for all who come: church atrium as well as presidency and park become sleeping places), as well as other arrangements.
To coordinate the logistics of the party of the third easter Friday and previous days. Since some brotherhoods arrived since Wednesday or Thursday to prepare what they delivered as promise (i.e. fireworks prepared since Wednesday to be lighted Thursday afternoon).

- $\quad$ Organized the purchase and delivery of supplies for food preparation: all men form the committee deliver ten corn maquilas -approximately $50 \mathrm{~kg}$ - and it was left in the houses to be grounded. Also, beans, rice, pepper and shrimp were delivered to be prepared (breakfast, lunch and dinner for four days) by the women in the 25 houses of every commissioner 15 days before for the early-arrived people, being retired by Saturday after lunch.

To cooperate and collect 300 pesos from each one of the committee members, as well as corn, beans and rice delivery.

\subsection{One year-activities of Santo Domingo Tonahuixtla butler. Actividades en un año del mayordomo en Santo Domingo Tonahuixtla}

January to March: Develop stewardship activities, working days of 19 hours to invite the brotherhoods. The butler and commission stop working in the country to fully dedicate to stewardship management through celebration day (normally in march or April) May to October: country work, corn sown. November to December: harvesting

\subsection{Selection process of the stewardship of San Rafael Comac and Santo Domingo Tonahuixtla}

According to Mr. Ocoxtle, butler in turn, he has to look for his substitute, in case that there were none, the butler in turn would repeat one year more. "Future butler should be a married, responsible, tradition respectful and willing to make the expenses that the management requires man" (Barrera, 1992:106). As mentioned by the 2015-2016 period butler, of San Rafael Comac and his wife, today there are many people rejecting stewardship because "things are more expensive". However, there are couples that gladly accept this position to serve God. 
Also, Mr. Ocoxtle, relates with pleasure, that his mother in law, brother in law, sister in law and dad has been in different church positions through the years.

In Santo Domingo Tonahuixtla, process selection isn't the same, as Mr. Martínez mentioned: "when you reach and older age, they designate people, you don't get to decide, when the town sees that someone has the possibility and is married, is nominate to participate". Position notice comes from both the ecclesiastic President and assistant President to reinforce the importance of this obligation. Also, a secretary, treasurer and spokesmen are selected to collaborate for the cause until a 25 member team is achieve. A sport committee is designated which is in charge of activities' organization such as basquetball, baseball, volleyball and rodeo.

Mr. Martínez mention that currently the stewardship of "Lord Tepalcingo" in Santo Domingo Tonahuixtla no longer is known under the same name, but now is known as the "Proparty committee". However, the same name remain existing in smaller celebrations.

\section{Faith as a resilient method}

Faith is the base of butler's behavior. It is a value that has allowed to preserve religious traditions and overcome life adversities.

\subsection{Religious basis of the stewardship: tradition preservation and devotion to "Serve the Lord"}

According to several interpretation in the old and new testament, Catholics base their "service to the Lord" in the "giving money". Since money obtained through work is human life in its concrete form and therefore, the earned money is a vital factor of spiritual life and in the material progress, the son of God must face his responsibility as a butler who finally will be judge before Christ court" (Ro. 14:10-12, cited in Sperry, 2010). In this sense, and from stewardship's point of view and the people who has been in this position in several towns, giving money to serve God is not only necessary but also honorable.

In San Rafael Comac, the butler will give his own money, time and work in the Lor disposition, since He has chosen him to serve Him.
According to Sperry interpretation (2010) of Corinthios 2, 8:1-9:15 being "under God grace" is define as:

Christ's gift was from His profound poverty (2 Co. 8:2). Under God grace, isn`t looking for the gift when giving, but a devotion expression from the giver. Under the grace there are no laws and there aren't stablished any proportion in giving. God holds the giver. God will hold the grace offering with his unlimited temporary resources (2 Co. 9:8-10; Lc. 6:38). Blessing are granted because the heart has been expressed through the offering. It is clear that there won't be any offering made to God form the heart that He won't acknowledges in his grace.

Now, form the point of view of tradition preservation, Ramírez (2000:163) question: "Should we maintain or abandon traditions? Is it true that in modern society traditions are dying and are no longer redeemable? Is the only thing that can save us from excesses and uneasiness of the modern world, the return of the tradition and restore of the forgotten?"

To address this issues, in first place, it has to be defined what a tradition is. According Pieper (2000) is not only the "oral transmission of the Christian true" (Dictionnaire de Théologie Catholique, 1253 vol. 15, 1, col, cited in Pieper, 2000: 243), nor "the transmission of the possessed with property transfer intention" (Sohm, R. 1905: 309 cited in Pieper, J. 2000: 243), it is all about "preserving against time passing, identical through all the change something given in anticipation" (Pieper, 2000: 238), or "the continuous permanency of life in the change of the vital phases (Krüger, 1951: 22 y 13, cited in Pieper, 2000: 244). Also, always keeping two actors in the process, the one who transmits and the one to whom it is transmitted: the tradition, which could be any element of the thinking or human action: music, principles, values, doctrines, behaviors, parties, celebrations, and others.

Base in the aforementioned and addressing some of the questions asked by Ramírez (2000), this study pretends to approach resilience maintained by the butlers from the perspective of preserving the tradition in their societies, either as a service, love, civilian fulfillment, religious believes, faith and social commitment act.

MORALES-PAREDES, Yesbek Rocío, CERÓN-CARRILLO, Teresa Gladys, SANTIESTEBAN-LÓPEZ, Norma Angélica and MALDONADO-RESÉNDIZ, Jorge Ángel. Stewardship: Tradition preservation, resilience based on faith. ECORFAN Journal-Republic of Colombia. 2020 
Based on the above, and responding to some of the questions raised by Ramírez (2000), this study will try to address the resilience that mayordomos will maintain from the perspective of the preservation of said tradition in their respective societies, either as a act of service, love, civil fulfillment, religious belief, faith or social commitment.

\subsection{Resielence}

For Erick Wolf (1996, cited in Montes y Montes: 87) position system (stewardship) is a defense and protection mechanism to all the external threats and the movement center of the communities that have this tradition. Some researches (...) assume that Mesoamerican traditions were destined to disappear before modernity attack and political system. However, towns have developed a spectrum of cultural adaptation strategies to economic competition and environmental degradation. In towns, position system and festivities has had to recreate for not to succumb, through their tradition reinvention (Hosbawm y Ranger, 1983, cited in Ortega y Mora, 2014: 51).

This asseveration is still effective nowadays according to Ochoa (2007:12), Now, stewardship system is still valid constituting a characteristic feature of the religious organization in community interior, mainly rural origin".

With regard to resilience ${ }^{1}$, Cárdenas y López (2011: 530-533) in their research about old age resilience, they made a review of 33 scientific studies in which they obtained 31 different definition of the word, concluding that each one of these definitions ha a common structure based in four elements:

1. Feature type: resilience is thought as an ability or personal capacity, as a positive personality characteristic, as a transactional process or as adaptative capacity in most of the written reviews.

\footnotetext{
${ }^{1}$ Resilience has multiple definitions rom which only some are mentioned in Annex 2 of this work. In the same way, this project pretended to provide a definition El término de resiliencia tiene múltiples definiciones, de las cuales solo algunas se mencionan en el anexo 2 del presente trabajo. En este sentido, en este proyecto se pretendió dar una definición que abarque todo aquello que la autora percibió en la vida de los entrevistados.

ISSN-On line: 2539-1372

ECORFAN® All rights reserved.
}

2. Its manifestations: all those process related to resource preservation posed by individuals before hostile events, those in which altered, modified or lost resources are recovered as a side effect of a adverse events. Also, positive results generated by the people in adversity and finally, those process in which the accomplishment of this results wouldn't be feasible.

3. Life dimensions in which resilience is an evidence: physical and/or emotional health, functional status, capacities, equilibrium and life quality.

4. Environmental demands in which resilience is shown: is the environment in which people get developed.

So, the sense of resilience that this work pretend comes from the next affirmation: "Stewardship is, of all the church positions, the only one that needs to pay out a large amount of money for food expenses" (Ochoa, 2007: 8-9) and the expenditure of the management, as well as time and dedication without any pay back in exchange, but the "serve to God" satisfaction, believes preservation and accomplishment of a given task as a citizen.

It is convenient to say that the members of the main butler's nuclear family along with its extensive families (married sons and daughters along with their husbands and wives and their respective child) are the one that helps to pay the expenses and participate in festivities' food and drink preparations. Butler's wife is the one who inherits responsibilities hired by her husbands, according to Montiel (2002: 9, cited in Ochoa, 2007: 9) about stewardship in San Jeronimo Amanalco, Texcoco.

The situation isn't different in San Rafael Comac since in words of Mr. Ocoxtle even though, when a 35-person commission is formed for them to contribute withh the expenses in the one-year management, isn't enough to cover all the expenditures. According to the interviewed, he has to pay for the surplus, mentioned that "God gives" and the resources will be obtained from the work to satisfy the "carguito".

MORALES-PAREDES, Yesbek Rocío, CERÓN-CARRILLO, Teresa Gladys, SANTIESTEBAN-LÓPEZ, Norma Angélica and MALDONADO-RESÉNDIZ, Jorge Ángel. Stewardship: Tradition preservation, resilience based on faith. ECORFAN Journal-Republic of Colombia. 2020 
In the same way, food preparation is in charge of butler's wife who besides, will lend her house to perform the traditional festivities. Stewardship management in San Rafael Comac 2015-2016, was calculated to generate expenses for $\$ 450,000.00$, from which, only $\$ 145,000.00$ were given by the commission and the rest were contribute by the butler and his couple, since no one in the town contribute with any economic or in kind contribution.

In the case of Santo Domingo Tonahuixtla stewardship, Mr. Martínez declares that in his management period there were collected from $\$ 45,000.00$ to $\$ 50,000.00$, from which the 25- people commission, contributed with $\$ 7,500.00$ (\$300.00 per person and in the case in which someone didn't have the money, since most peasants had less than 10 pesos per day wage, they sold a cow or a goat or as Mr. Martínez case, they would ask borrowed to another person who had more cattle in the town, repeating this every one of the three-year management. In case of get any debt with another member of the community, and once the celebration has passed, stewardship commission would look for another job in Puebla and México City to pay the debt.

In present time, more than $\$ 250,000.00$ pesos are collected for the celebration and the former butlers keep contributing year after year. Mr. Martínez conformed a Civilian Association in México city and through this, he keep cooperating with money for the town celebration.

Against this background it is stablished that this tradition contribute with resilience of whose that have a position as butler in different communities (either for the motivation to serve or to comply as a citizen), understanding this in the present work as: recovery and development of people against environmental adversities which could be either individual or collective, of different nature (economic, social, cultural, spiritual, etc.) being also for one time only or constant through time. With this it can be achieve people adaptation whose could be subjected to new adversities and problems.
And since, doesn't matter neither the economic situation if the couple and the supporting committee nor the fact that they should dedicate lots of hours in reunions, masses, food preparation and the effort that implies this activity in all senses, what really matter is to give and deliver from the heart as much as possible for the satisfaction and Grace of the Lord, with whatever accomplished to preserve the tradition for centuries.

Then, the resilience from the interviewed butlers in this project for comply with the position's activities, it shows no just in faith, surrender and courage used to prepare religious celebrations, but in the money inverted given with the fervent conviction to serve the Lord, no matter that, in order to achieve this, involves extenuating work days, loan requests and time dedicated to funds recollection (either from door by door, community to community or even with friends and family), food preparation, nativity settings and other activities related to the stewardship position.

\section{Methodology and method}

Qualitative investigation methodology: oral History.

Qualitative methods produce descriptive and interpretative data through which people talk or write with their own words the observed behavior (Berríos, 2000, cited in Charriéz, 2012: 50). With this in mind, for this study it was decided to used Oral History method defined as " the broad term that covers a quantity of stories regarding the unregistered facts for other type of documentation or whose documentation wanted to be completed captured by interviews of various forms registering an individual or group experiences in one collectivity" (Pereira de Queiroz 1991:5, cited in Veras, 2010: 144).

Meyer, E. and Olivera, A. (1971: 372), mention: what oral history pretends is to collect virgin material that could be used later (...) it provides generally fresh material. To a large extend, oral history is the gathering of interviews with outstanding characters (..) or with individuals that witness fundamental facts, where the researcher must rescue this testimonies. 
In these testimonies, may be reflected feelings and personal attitudes against boring facts, which led to a singular matrix of the related histories according to the interviewed subject (according his vision) since, in agreement to Taylor and Bogdam (1984 cited in Charriéz, 2012: 51) socially constructed reality through collective or individual definitions of a given situation.

Base on the above, this study pretends to understand the interpretation given by the interviewed; their life conducts, attitudes, feelings and representation related to the stewardship.

This research is based in interviews and visits to the 2015-2016 period butler of San Rafael Comac, Mr. Rafael Ocoxtle Jiménez, and Mr. Delfino Martínez, Butler from Sano Domingo Tonahuixtla in $1976-1978$ period, as well as the population observation and their religious traditions.

In these interviews general data were obtained from they and their families as well as relevant information from his previous stewardship management. This is done, to show that this tradition preservation through time has been a basic element of resilience for the catholic and devoted settlers of San Rafael Comac and Santo Domingo Tonahuixtla. Openning interview instrument is shown in Annex 1.

\section{Results}

Being San Rafael Comac and Santo Domingo Tonahuixtla butler is a great honor because allow to have the opportunity to "serve the Lord" and a citizenship responsibility and as believer, that needs to be executed with all the seriousness and submission possible.

For Mr. Rafael Ocoxtle Jiménez, the idea of become a butler again is not contemplated for now: "Maybe, over time, but no for now because of the expenses and to give other persons the opportunity to serve. It is nice due to the coexistence and tradition preservation". Also, in his wife words against the same question she mentioned: "You never know, only God does". According to the interviewed couple, the option of being butlers soon next year it is no viable, however, with a smile in their faces, mentioned that they will be willing to serve the Lord in other circumstances with a great sense of commitment and love.
Mr. Martínez form Santo Domingo Tonahuixtla mentioned that being a butler is a very difficult task due to the long working days when it is time to invite ither town brotherhoods. However, indicates that being in that position left him with the satisfaction of having accomplished responsibly as a citizen and a believer that the Lord of Tepalcingo wants and he will recommend to live this experiences to his families and close persons.

\section{Annexes}

\section{Annex 1: Butler interview}

\begin{tabular}{ll} 
1. & Name \\
2. & Age \\
3. & Stewardship period \\
4. & Occupeation before stewardship \\
5. & Actual occupation \\
6. & Time with this occupation \\
7. & Waiting time for being a butler \\
8. & Why do you decide to be a butler? \\
- & Tradition \\
- & Heritage \\
- & Honor \\
- & Promise \\
- & Obligation \\
- & Other \\
9. & What are the wrights and obligation of \\
& the stewardship? \\
- & Celebration activities (of the church and \\
& settlers) \\
- & Masses \\
- & Processions \\
- & Managerial Activities \\
- & Fundraising for church \\
- & Other: \\
10. & What other designations are given during \\
11. & Whe stewardship? \\
- & resources for the stewardship? \\
- & Personal savings \\
- & Mexican Family \\
- & Donation family \\
- & Community \\
- & Other: \\
\hline
\end{tabular}

12. How much is the cost of all the inversion made during the stewardship period?

13. Do you acquire some kind of debt during the stewardship? With whom? If so, Do you still have this debt? How much is the debt?

MORALES-PAREDES, Yesbek Rocío, CERÓN-CARRILLO, Teresa Gladys, SANTIESTEBAN-LÓPEZ, Norma Angélica and MALDONADO-RESÉNDIZ, Jorge Ángel. Stewardship: Tradition preservation, resilience based on faith. ECORFAN Journal-Republic of Colombia. 2020 
14. Did the community help you with some kind of resource?

- $\quad$ Economic

- $\quad$ Food and beverage

- Food service

- House cleaning services

- $\quad$ Product donation for the stewardship

- Other:

15. What benefits do you have when being a butler?

- Espirituals

- Economics

- Ocuppational

16. After your period as a butler do you obtain some kind of job offer?

17. Would you be a butler again or would you recommend it to someone close? Why?

\section{Annex 2: Resilience definitions}

According to Ospina (2007: 58) it is understood as a dynamic process that implies both the adversity exposition in a significative context and the overcoming of this adversity and the successful adaptation of the person.

Is also understood as the capacity of each individual in a poverty environment to overcome the adversity in benefit of personal growth (Anzola, 2003: 191). Cyralnyk (2002, cited in Anzola, 2003: 91) defines it as a self-protective mechanism that is moving since the most tender childhood absorbing trauma shocks first by affective bond weaving and then through the emotion expressions.

Resilience, is define by some authors working through it " as the human capacity to face, overcome, being fortified and transformed by adversity experiences" (Grotberg, 2006: 18, cited in Valdebenito, Loizo y García, 2009: 196197). Other, mos especifically pose that "to be resilience is to recover, going forward after an illness, trauma or stress" (Manciaux, 2001: 24, cited in Valdebenito, Loizo y García, 2009: 197). This mark the possibility of each individual to overcome to the tests and life crisis; i.e. first resist them to overcome them later, to keep on living as best as possible.

\section{Aknowledges}

To Mr. Rafael Ocoxtle and Delfino Martínez for sharing their stories and knowledge to preserve their traditions.

\section{Conclusions}

Stewardship is a religious tradition that has persist through social, cultural, economics and political changes of our country. Besides, is a strongly rooted custom in several Mexican populations. It is an honor and service to God activity, as shown by those who practice and preserve it.

The present work has the objective of emphasize resilience show by the people who accept stewardship position in their community. For although being butler implies a strong economic, time and effort investment, without any kind of payment in return: those who has been butlers have service and love satisfaction for the rest of their lives.

It consist in a task from the heart of the best way possible and with the resources provided by the Lord. It is a tradition of hundreds of years that remains alive by their practitioners faith presented as an example of the people capacity to stand up and keep forward seeking for personal, community, social, spiritual and cultural growth, even though, there are adversities in the path that seems impossible to manage.

Interviewed people declared that although with the stewardship's demands, tradition preservation to serve the Lord and the community is primordial and it should persist over the time. In the case of Mr. Martínez, Civilian Association conformation, which provide economic resources to the stewardship celebration year after year, is the reflection of the importance of preserve the activity, of being resilience before modern world changes to defend their customs. Today at his 70 years old, Mr. Delfino Martínez keep managing fundraising from believers and family to prepare the third easter Friday celebration in Santo Domingo Tonahuixtla. In the interview, Mr. Martínez declare that after living 34 years in Mexico City, he decided to came back to his town, to his roots, where the traditions are still alive and respected.

This is only a brief description of a tradition that brings joy to the heart of those who live it, it is an invitation for researches to deepen in this subject from different perspectives. 


\section{References}

Anzola, Myriam. (Julio- septiembre 2003). "La resiliencia como factor de protección". Educere. 7: 22.

Barrera, Estanislao. (1992). "La mayordomía entre los otomíes". La palabra y el hombre. 81: 97-120

Cárdenas, Andrea y López, Alba. (Junio 2011). "Resiliencia en la vejez". Revista de Salud Pública, 13: 528-540.

Charriéz, Mayra. (Diciembre de 2012). "Historias de vida: Una metodología de investigación cualitativa". Revista Griot. 5: 5067.

Fernández, José; Hernández, Pilar; Enríquez, Jeús; et al. (2010a). San Andrés Cholula. Enciclopedia de los Municipios y Delegaciones de México. H. Ayuntamiento de San Andrés Cholula. Instituto Nacional para el Federalismo y el Desarrollo Municipal.

Fernández, José; Hernández, Pilar; Enríquez, Jeús; et al. (2010b). San Jerónimo Xayacatlán. Enciclopedia de los Municipios y Delegaciones de México. H. Ayuntamiento de San Jerónimo Xayacatlán. Instituto Nacional para el Federalismo y el Desarrollo Municipal.

Gobierno Municipal de San Andrés Cholula (2015). Historia. Conformación del municipio de San Andrés Cholula.

Instituto Nacional de Estadística y Geografía (2005). Áreas geográficas. Disponible en: https://www.inegi.org.mx/datos/default.html?t= 0120\#Areas_geograficas (consultado: $10 \mathrm{de}$ abril de 2019).

Martínez, Delfino (2018). Entrevista realizada al mayordomo de Santo Domingo Tonahuixtla en el periodo 1976- 1978. 20 de noviembre de 2018.

Mejía, María. (2005). "Reseña de Cofradías, caciques y mayordomos: Reconstrucción social y organización política en los pueblos de indios, Siglo XVIII de María Lucía Sotomayor". Anuario Colombiano de Historia Social y de la Cultura. 31: 360- 362.

Meyer, Eugenia y Olivera, Alicia. (1971). "La Historia oral. Origen, metodología, desarrollo y perspectivas". Historia Mexicana. 21: 372-387.

ISSN-On line: 2539-1372

ECORFAN® All rights reserved.
Montes, Olga y Montes, Néstor. (Juliodiciembre 2014). "La mayordomía en un barrio de la Ciudad de Oaxaca". Frontera Norte. 26: 85- 108.

Ochoa, Teresa. (2007). "La dominación masculina en el sistema tradicional de cargos: El caso de San Jerónimo Amanalco, Municipio de Texcoco, México". Iberoforum. Revista de Ciencias Sociales de la Universidad Iberoamérica. 2: 1- 19.

Ocoxtle, Rafael (2018). Entrevista realizada al mayordomo de San Rafael Comac periodo 20152016. 16 de noviembre de 2018.

Ortega, Mario y Mora, Fabiola (2014). "Mayordomías y fiestas patronales en los pueblos originarios de Santa Ana Tlacotenco y Santiago Tzapotitlan, nahuas del Distrito Federal, México". Diálogo andino, (43), 51-63

Ospina, Doris. (Marzo 2007). "La medición de la resiliencia". Investigación y educación en enfermería. 25: 58-65.

Pieper, Josef. (2000). Escritos sobre el concepto de filosofía. Madrid: Ediciones encuentro.

Ramírez, Mario. (2000). El tiempo de la tradición. Relaciones. Estudios de historia y sociedad. 21: 161-185.

Sperry, Lewis. (2010). La iglesia: su servicio y mayordomía. Disponible en: http://www.seminarioabierto.com/doctrina237.h $\mathrm{tm}$

Veras, Eliane. (2010). "Historia de Vida: ¿Un método para las ciencias sociales?". Cinta moebio. 39: 142-152.
MORALES-PAREDES, Yesbek Rocío, CERÓN-CARRILLO, Teresa Gladys, SANTIESTEBAN-LÓPEZ, Norma Angélica and MALDONADO-RESÉNDIZ, Jorge Ángel. Stewardship: Tradition preservation, resilience based on faith. ECORFAN Journal-Republic of Colombia. 2020 